\title{
The Reaction of Cobalt Hydrocarbonyls Substituted by Tertiary Phosphines with an Olefin*
}

\author{
by Masato Tanaka**, Yoshihisa Watanabe***, Take-aki Mitsudo***, \\ and Yoshinobu Takegami***
}

\begin{abstract}
Summary: The carbonylation reaction of ethyl vinyl ether with various cobalt hydrocarbonyls, $\mathrm{HCo}(\mathrm{CO})_{4}, \mathrm{HCo}(\mathrm{CO})_{3} \mathrm{PR}_{3}, \mathrm{HCo}(\mathrm{CO})_{3} \mathrm{P}(\mathrm{OR})_{3}$, and $\mathrm{HCo}(\mathrm{CO})_{2}\left[\mathrm{P}(\mathrm{OR})_{3}\right]_{2}$ was studied. Almost all of the cobalt hydrocarbonyls react with ethyl vinyl ether to form the branched chain acyl complexes, $\mathrm{CH}_{3} \mathrm{CH}\left(\mathrm{OC}_{2} \mathrm{H}_{5}\right) \mathrm{COCO}(\mathrm{CO})_{4-n} L_{n}\left(\mathrm{~L} ; \mathrm{CO}, \mathrm{PR}_{3}\right.$, and $\left.\mathrm{P}(\mathrm{OR})_{3}\right)$, regardless of the character of the ligands at $0 \sim 25^{\circ} \mathrm{C}$, while $\mathrm{HCo}(\mathrm{CO})_{2}\left[\mathrm{P}(\mathrm{OEt})_{3}\right]_{2}$ does not react even at $65^{\circ} \mathrm{C}$. The order of the reactivities is parallel to that of the electron-accepting character of the ligand. The addition of an excess of the ligand retards the reaction. The activation parameters of the reaction of $\mathrm{HCo}(\mathrm{CO})_{3} P P h_{3}$ with ethyl vinyl ether were estimated to be $\Delta H^{\neq}=9.88 \mathrm{kcal} / \mathrm{mol}, \Delta S \neq=-41.0$ e.u.
\end{abstract}

\section{Introduction}

Though dicobalt octacarbonyl has been conventionally used as a catalyst in the hydroformylation of olefins, cobalt carbonyl phosphine complexes are also active, and many papers on these modified catalysts have been published ${ }^{1}$. The modified catalysts are postulated to act as complexes of the type $\mathrm{HCo}(\mathrm{CO})_{3} \mathrm{~L}$ ( $\mathrm{L}$; a phosphorus ligand) and the effects of phosphine ligands on the hydroformylation reaction are explained from the viewpoint of the bulkiness and the basicity of the phosphorus ligand. Little attention, however, has been paid to the stoichiometric carbonylation reactions of these substituted cobalt hydrocarbonyls with olefins, and only several properties of $\mathrm{HCo}(\mathrm{CO})_{3} \mathrm{~L}$ such as acidity, IR and NMR spectra have been examined ${ }^{2)}$.

The purpose of this investigation is to examine the reactions of the substituted cobalt hydrocarbonyls with ethyl vinyl ether, which was selected as the most convenient olefin for this study because of its high reactivity to cobalt hydrocarbonyl.

\section{Experimental}

Cobalt hydrocarbonyl in $n$-hexane was prepared analogously as in the previous paper ${ }^{3)}$. Tri-ptolylphosphine, tri-p-anisylphosphine and tri-pchlorophenylphosphine were prepared according

* Received September 27, 1974.

** National Chemical Laboratory for Industry (Honmachi 1, Shibuya-ku, Tokyo 151)

*** Department of Hydrocarbon Chemistry, Faculty of Engineering, Kyoto University (Kyoto 606) to the literature ${ }^{4}$. The other organic compounds used were commercial products and purified in the usual manner.

IR spectra were recorded on a Hitachi 215 grating infrared spectrometer. NMR spectra were measured with a JEOL $3 \mathrm{H}-60$ and a Varian HR-220 spectrometer. Gas chromatography was carried out by Yanagimoto G8 apparatus equipped with a stainless steel column packed with dilauryl phthalate $(20 \%)$ on celite $\left(3 \mathrm{~mm}^{\phi} \times 2.25 \mathrm{~m}\right)$.

\subsection{The Reaction of $\mathrm{HCo}(\mathrm{CO})_{4}$ with Ethyl Vinyl Ether}

To a solution of $\mathrm{HCo}(\mathrm{CO})_{4}(3 \mathrm{mmol})$ in $n$ hexane $(20 \mathrm{~m} l)$, ethyl vinyl ether $(0.86 \mathrm{~m} l, 9 \mathrm{~m}$ mol) was added at $0^{\circ} \mathrm{C}$, and the reaction mixture was agitated under carbon monoxide. In the first $15 \mathrm{~min}$, the uptake of the carbon monoxide reached $0.6 \mathrm{~mol} / \mathrm{mol}-\mathrm{HCo}(\mathrm{CO})_{4}$. A $2.0 \mathrm{ml} \mathrm{sam}$ ple of the solution was removed, and quenched with a solution of iodine in ethanol, followed by reduction of excess of iodine with sodium thiosulfate. Gas chromatography of the resultant solution indicated the formation of ethyl $\alpha$ ethoxypropionate (yield $\sim 30 \%)^{5}$ ).

\subsection{The Reaction of $\mathrm{HCo}(\mathrm{CO})_{3} \mathrm{PPh}_{3}$ with Ethyl Vinyl Ether}

A $n$-hexane solution $(7.8 \mathrm{ml})$ of $\mathrm{HCo}(\mathrm{CO})_{4}$ ( $3 \mathrm{mmol}$ ) was added to a tetrahydrofuran solution $(7.8 \mathrm{~m} l)$ of triphenylphosphine $(0.786 \mathrm{~g}$, $3 \mathrm{mmol}$ ) at $-40^{\circ} \mathrm{C}$ under carbon monoxide and $3 \mathrm{mmol}$ of carbon monoxide was immediately evolved. To the resultant solution, ethyl vinyl ether $(2.9 \mathrm{~m} l, 30 \mathrm{mmol})$ was added at $0^{\circ} \mathrm{C}$. 
Table 1 'l'he Carbonylation Reaction of Cobalt Hydrocarbonyls with Ethyl Vinyl Ether*1

\begin{tabular}{|c|c|c|c|}
\hline $\mathrm{HCo}(\mathrm{CO})_{4-n} \mathrm{~L}_{n}$ & $\begin{array}{l}\text { Time } \\
\text { (hr) }\end{array}$ & $\begin{array}{c}\mathrm{CO} \text { Absd. } \\
\left(\mathrm{mol} / \mathrm{mol}-\mathrm{HCo}(\mathrm{CO})_{4-n} \mathrm{~L}_{n}\right)\end{array}$ & $\begin{array}{l}\text { Yield of Ester*2 } \\
(\%)\end{array}$ \\
\hline $\begin{array}{l}\mathrm{HCo}(\mathrm{CO})_{4}{ }_{4}^{* 3} \\
\mathrm{HCo}(\mathrm{CO})_{3} \mathrm{P}\left(p-\mathrm{Cl}-\mathrm{C}_{6} \mathrm{H}_{4}\right)_{3} \\
\mathrm{HCo}(\mathrm{CO})_{3} \mathrm{PPh} \\
\mathrm{HCo}(\mathrm{CO})_{3} \mathrm{P}(p-\text { tolyl })_{3} \\
\mathrm{HCo}(\mathrm{CO})_{3} \mathrm{P}(p-\text { anisyl })_{3} \\
\mathrm{HCo}(\mathrm{CO})_{3} \mathrm{~PB}{ }_{3}^{n} \\
\mathrm{HCo}(\mathrm{CO})_{3} \mathrm{P}(\mathrm{OPh})_{3} \\
\mathrm{HCo}(\mathrm{CO})_{3} \mathrm{P}(\mathrm{OEt})_{3} \\
\mathrm{HCo}(\mathrm{CO})_{2}\left[\mathrm{P}(\mathrm{OPh})_{3}\right]_{2} \\
\mathrm{HCo}(\mathrm{CO})_{2}\left[\mathrm{P}(\mathrm{OEt})_{3}\right]_{2}\end{array}$ & $\begin{aligned} & 0.15 \\
& 0.15 \\
& 1 \\
& 1 \\
& 1 \\
& 1 \\
& 24 \\
& 1 \\
& 1 \\
& 24\end{aligned}$ & $\begin{array}{l}0.56 \\
0.45 \\
0.44 \\
0.31 \\
0.21 \\
0.30 \\
0.38 \\
0.17 \\
0.60 \\
\text { No reaction }\end{array}$ & $\begin{array}{l}30^{* 4} \\
40 \\
= \\
= \\
= \\
\overline{58} \\
-\end{array}$ \\
\hline $\begin{array}{ll}* 1 & 0^{\circ} \mathrm{C} \text { under one atm of } \\
* 2 & \text { Yield of ethyl } \alpha \text {-ethox } \\
* 3 & \text { Ethyl vinyl ether used } \\
* & 1,1,2-\text { Triethoxypropan }\end{array}$ & base & $\begin{array}{l}\text { m) }{ }_{4-n} \mathrm{~L}_{n}: 3 \mathrm{mmol} \text {, ethyl vin } \\
\text { mount of } \mathrm{HCo}(\mathrm{CO})_{4-n} \mathrm{~L}_{n} \\
15 \%) \text {. }\end{array}$ & $\mathrm{mmol}$ \\
\hline
\end{tabular}

After $3 \mathrm{mmol}$ of carbon monoxide was taken up, the reaction mixture was filtered, and the filtrate was concentrated and cooled to give a pale yellow powder. Treatment of this powder with iodine in ethanol gave ethyl $\alpha$-ethoxypropionate, and IR NMR spectra indicated the powder to be an acylcobalt complex, $\alpha$-ethoxypropionyl (tricarbonyl) (triphenylphosphine) cobalt. IR (KBr): ${ }^{\circ} \mathrm{CO} 2,040,1,980$ and 1,960, and acyl $1,655 \mathrm{~cm}^{-1}$; NMR (in $\left.\mathrm{C}_{6} \mathrm{D}_{6}\right): \tau 7.6-6.9(\mathrm{~m}, 15 \mathrm{H}$ ), $3.88(\mathrm{q}, 1 \mathrm{H}), 3.39(\mathrm{q}, 2 \mathrm{H}), 1.39(\mathrm{~d}, 3 \mathrm{H})$, and 1.19 (t, $3 \mathrm{H})$. Molecular weight: obsd.; 514, calcd. for $\mathrm{C}_{26} \mathrm{H}_{24} \mathrm{O}_{5} \mathrm{PCo} ; 506$.

The procedure for the reactions of the other cobalt hydrocarbonyls with ethyl vinyl ether was almost the same as described above.

\section{Results and Discussion}

\subsection{The Reaction of Cobalt Hydrocarbonyls with Ethyl Vinyl Ether}

Stoichiometric carbonylation reactions of various cobalt hydrocarbonyls with ethyl vinyl ether were examined in $n$-hexane or the mixed solvent of $n$-hexane-tetrahydrofuran (1:1) at $0^{\circ} \mathrm{C}$ under one atm of carbon monoxide, and the results are summarized in Table 1.

$\mathrm{HCo}(\mathrm{CO})_{4}$ reacted rapidly with ethyl vinyl ether with the absorption of carbon monoxide under a very mild condition. When the reaction mixture was treated with a solution of iodine in ethanol, two organic compounds were obtained, one was ethyl $\alpha$-ethoxypropionate which was undoubtedly derived from $\alpha$-ethoxypropionyl (tetracarbonyl)cobalt, and the other was $1,1,2$ triethoxypropane. It was ascertained that the latter was formed when $\alpha$-ethoxypropionaldehyde was treated with iodine in ethanol. No organic compounds derived from the straight chain acyl complex were detected by gas chromatography. The result shows that $\alpha$-carbon was selectively carbonylated in the reaction of $\mathrm{HCo}(\mathrm{CO})_{4}$ with ethyl vinyl ether, and that some part of the branched chain acyl complex was easily reduced with $\mathrm{HCo}(\mathrm{CO})_{4}$ into the corresponding aldehyde.

$$
\begin{aligned}
& \stackrel{\mathrm{CH}_{2}=\mathrm{CHOEt}+\mathrm{HCo}(\mathrm{CO})_{4}}{\mathrm{CO}}\left[\mathrm{CH}_{3} \mathrm{CH}(\mathrm{OEt}) \mathrm{COCo}(\mathrm{CO})_{4}\right] \\
& \left.\stackrel{\mathrm{HCo}(\mathrm{CO})_{4} \stackrel{\mathrm{I}_{2}-\mathrm{EtOH}}{\longrightarrow} \mathrm{CH}_{3} \mathrm{CH}(\mathrm{OEt}) \mathrm{COOEt}}{\left.\mathrm{CH}_{3} \mathrm{CH}(\mathrm{OEt}) \mathrm{COCo}(\mathrm{CO})_{4}\right]} \underset{\mathrm{I}_{3}-\mathrm{EtOH}_{3}}{\longrightarrow} \mathrm{CH}_{3} \mathrm{CH}(\mathrm{OEt}) \mathrm{OH}\right) \mathrm{CH}(\mathrm{OEt})_{2}
\end{aligned}
$$

Mono-substituted cobalt hydrocarbonyls, HCo$(\mathrm{CO})_{3} \mathrm{~L} \quad\left(\mathrm{~L}=\mathrm{PR}_{3}, \mathrm{P}(\mathrm{OR})_{3}\right)$, made in situ from $\mathrm{HCo}(\mathrm{CO})_{4}$ and phosphorus ligands, also reacted smoothly with ethyl vinyl ether under mild conditions. By the iodine-ethanol treatment of the reaction mixture, ethyl $\alpha$-ethoxypropionate was formed in every case. In the reaction of $\mathrm{HCo}$ $(\mathrm{CO})_{3} \mathrm{PPh}_{3}$, a pale yellow powder was isolated as a product, which was identified as $\alpha$-ethoxypropionyl (tricarbonyl) (triphenylphosphine)cobalt. In other cases, oily substances, which were difficult to purify, were obtained, and they showed infrared absorption bands characteristic to acylcobalt complexes $\left(1,645 \sim 1,665 \mathrm{~cm}^{-1}\right)$. These results showed that these mono-substituted cobalt hydrocarbonyl also gave selectively branched chain acyl complexes in the reaction with ethyl vinyl ether.

$$
\begin{aligned}
\mathrm{CH}_{2}=\mathrm{CHOE} t & +\mathrm{HCo}(\mathrm{CO})_{3} \mathrm{~L} \\
& \stackrel{\mathrm{CO}}{\longrightarrow} \mathrm{CH}_{3} \mathrm{CH}(\mathrm{OEt}) \mathrm{COCo}(\mathrm{CO})_{3} \mathrm{~L}
\end{aligned}
$$

In the reaction of $\mathrm{HCo}(\mathrm{CO})_{4}$ with a phosphine, 
only one equivalent of carbon monoxide was evolved to give a mono-substituted cobalt hydrocarbonyl even if more than one mole of the phosphine per mole of $\mathrm{HCo}(\mathrm{CO})_{4}$ was added. On the other hand, in the case of a phosphite, two equivalents of carbon monoxide were evolved probably to give a di-substituted cobalt hydrocarbonyl. The reaction of ethyl vinyl ether with di-substituted cobalt hydrocarbonyls was also examined. $\mathrm{HCo}(\mathrm{CO})_{2}\left[\mathrm{P}(\mathrm{OPh})_{3}\right]_{2}$ reacted with ethyl vinyl ether at $0^{\circ} \mathrm{C}$ with absorption of carbon monoxide to give an oily product on evaporating the solvent. When the product was treated with an iodine-ethanol solution, ethyl $\alpha$-ethoxypropionate was formed. On the other hand, HCo$(\mathrm{CO})_{2}\left[\mathrm{P}(\mathrm{OEt})_{3}\right]_{2}$ did not react with ethyl vinyl ether even at the reflux temperature $\left(65^{\circ} \mathrm{C}\right)$.

Cobalt carbonyl-PR $\mathrm{R}_{3}$ or $\mathrm{P}(\mathrm{OR})_{3}$ catalyst system is more favorable for the formation of straight chain products (aldehydes and/or alcohols) than the conventional $\mathrm{Co}_{2}(\mathrm{CO})_{8}$ catalyst in the hydroformylation of $\alpha$-olefins ${ }^{1)}$. This has been explained on the viewpoint of the steric and the electronic factors of $\mathrm{HCo}(\mathrm{CO})_{3} \mathrm{~L}$ and $\mathrm{HCo}(\mathrm{CO})_{4}$. However, the results obtained here show that ethyl vinyl ether has a great tendency to form branched chain acyl complexes even in the reaction of cobalt hydrocarbonyl substituted by phosphines or phosphites. This is partly attributed to the structure of the olefin used.

Table 1 shows the order of reactivities of the cobalt hydrocarbonyls as follows:

$$
\begin{aligned}
& \mathrm{HCo}(\mathrm{CO})_{4}>\mathrm{HCo}(\mathrm{CO})_{3} \mathrm{P}\left(p-\mathrm{Cl}-\mathrm{C}_{6} \mathrm{H}_{4}\right)_{3} \\
& >\mathrm{HCo}(\mathrm{CO})_{3} \mathrm{PPh}{ }_{3}>\mathrm{HCo}(\mathrm{CO})_{3} \mathrm{P}(\mathrm{OPh})_{3} \\
& >\mathrm{HCo}(\mathrm{CO})_{3} \mathrm{P}(p \text {-tolyl })_{3}>\mathrm{HCo}(\mathrm{CO})_{3} \mathrm{P}(p- \\
& \text { anisyl })_{3}>\mathrm{HCo}(\mathrm{CO})_{3} \mathrm{P}(\mathrm{OEt})_{3}>\mathrm{HCo}(\mathrm{CO})_{2} \\
& {\left[\mathrm{P}(\mathrm{OPh})_{3}\right]_{2}>\mathrm{HCo}(\mathrm{CO})_{3} \mathrm{PBu}{ }_{3}^{n}>\mathrm{HCo}(\mathrm{CO})_{2}} \\
& {\left[\mathrm{P}(\mathrm{OEt})_{3}\right]_{2} .}
\end{aligned}
$$

This will be considered later.

\subsection{Kinetic Studies of the Carbonylation Reaction}

The rate of reaction of $\mathrm{HCo}(\mathrm{CO})_{3} \mathrm{PR}_{3}$ was monitored by following carbon monoxide uptake. Figure 1 shows that it obeys the first order rate equation:

$$
k_{1}=\frac{2.303}{t} \log \left[V_{\infty} /\left(V_{\infty}-V_{t}\right)\right]
$$

where $k_{1}, t, V_{t}$, and $V_{\infty}$ are the first order rate constant, reaction time and carbon monoxide uptake at the time $t$ and infinity, respectively. The rate constants observed under various con-

Volume 17, No. 1, April 1975

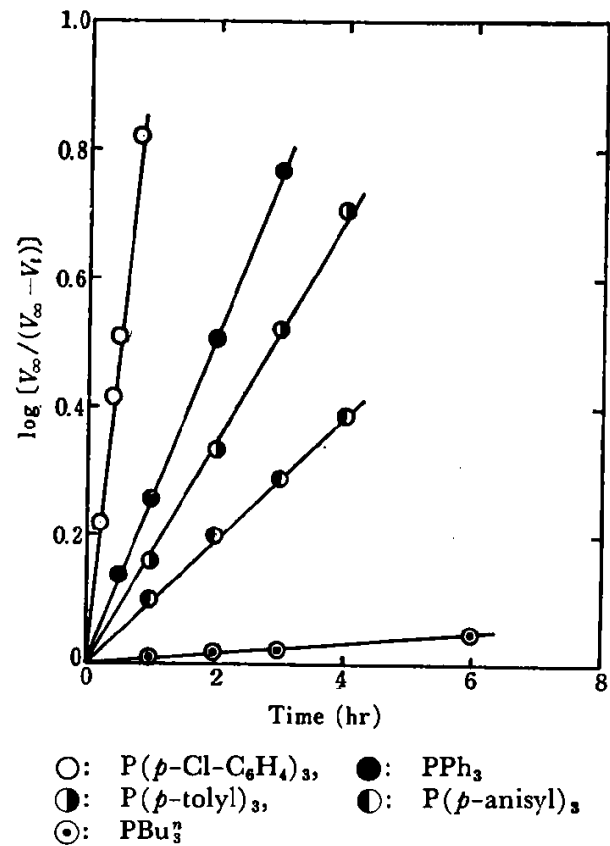

Fig. 1 Plots of $\log \left[V_{\infty} /\left(V_{\infty}-V_{t}\right)\right]$ against the Reaction Time $\left(0^{\circ} \mathrm{C}\right)$

ditions are summarized in Table 2. A change in the initial concentration of $\mathrm{HCo}(\mathrm{CO})_{3} \mathrm{PR}_{3}$ or of ethyl vinyl ether did not bring about any significant effects on the rate constant. This also confirms that the rate is first order with respect to the concentration of $\mathrm{HCo}(\mathrm{CO})_{3} \mathrm{PR}_{3}$.

\subsubsection{Effect of the Character of the Phos- phine Ligands}

Table 2 shows that the rate constants and the wave number of $\mathrm{CO}$ stretching $\left(\mathrm{A}_{1}\right.$ mode) are in parallel to each other, and that they decrease with changes in $\mathrm{L}$ in the order: $\mathrm{P}\left(p-\mathrm{Cl}-\mathrm{C}_{6} \mathrm{H}_{4}\right)_{3}>$ $\mathrm{PPh}_{3}>\mathrm{P}(p \text {-tolyl })_{3}>\mathrm{P}(p \text {-anisyl })_{3}>\mathrm{PBu}_{3}^{n}$. A coordination of a $\sigma$-donating ligand shifts downwards the wave number of $\mathrm{CO}$ stretching in general, and the results show that the stronger the electrondonating character of a phosphine ligand is, the slower the reaction proceeds. This consideration seems to be consistent with the order of the reactivities of the various mono- and di-substituted cobalt hydrocarbonyls mentioned above. An analogous order of rates is noted in the catalytic hydroformylation of l-hexene with $\mathrm{Co}_{2}(\mathrm{CO})_{8}-$ $\mathrm{PR}_{3}$ catalyst system ${ }^{6}$, and this is reasonably attributed to the reactivity of the substituted cobalt hydrocarbonyls formed under the oxo conditions.

\subsubsection{Effect of Addition of an Excess of the Phosphine Ligand}

It is known that both the distribution of pro- 
Table 2 Kinetic Study of the Carbonylation Reaction of Cobalt Hydrocarbonyls with Ethyl Vinyl Ether

\begin{tabular}{|c|c|c|c|c|c|c|}
\hline $\mathrm{PR}_{3}$ in $\mathrm{HCo}(\mathrm{CO})_{3} \mathrm{PR}_{3}$ & $\begin{array}{c}{ }^{\nu} \mathrm{CO}\left(\mathrm{A}_{1}\right) \\
\left(\mathrm{cm}^{-1}\right)\end{array}$ & $\underset{(\mathrm{M})}{\left[\mathrm{HCo}(\mathrm{CO})_{3} \mathrm{PR}_{\mathrm{s}}\right]}$ & $\underset{(\mathbf{M})}{\text { [Added } \mathrm{PR}_{\mathbf{3}} \text { ] }}$ & $\begin{array}{l}{[\mathbf{S}]^{*}} \\
(\mathbf{M})\end{array}$ & $\begin{array}{l}\text { Temp. } \\
\left({ }^{\circ} \mathrm{C}\right)\end{array}$ & $\begin{array}{l}k_{1} \times 10^{5} \\
\left(\sec ^{-1}\right)\end{array}$ \\
\hline $\mathrm{PPh}_{3}$ & $\begin{array}{r}2,048 \\
- \\
= \\
= \\
= \\
= \\
= \\
=\end{array}$ & $\begin{array}{l}0.162 \\
0.081 \\
0.324 \\
0.162 \\
" 1 \\
" \\
" \\
" \\
" \\
" \\
" \\
" 1 \\
"\end{array}$ & $\begin{array}{l}0 \\
0 \\
0 \\
0 \\
0 \\
0.0162 \\
0.0324 \\
0.0810 \\
0.1620 \\
0 \\
0 \\
0\end{array}$ & $\begin{array}{l}1.62 \\
1.62 \\
1.62 \\
0.81 \\
2.43 \\
1.62 \\
\text { " } \\
\text { " } \\
\text { " } \\
\text { " } \\
\text { " }\end{array}$ & $\begin{array}{c}0 \\
0 \\
0 \\
0 \\
0 \\
0 \\
0 \\
0 \\
0 \\
17.5 \\
-10.0 \\
-21.0\end{array}$ & $\begin{array}{c}17.3 \\
20.4 \\
18.9 \\
15.0 \\
15.9 \\
7.08 \\
4.32 \\
1.62 \\
0.70 \\
49.5 \\
8.10 \\
3.11\end{array}$ \\
\hline $\begin{array}{l}\mathrm{P}\left(p-\mathrm{Cl}-\mathrm{C}_{6} \mathrm{H}_{4}\right)_{3} \\
\mathrm{P}(p \text {-tolyl })_{3} \\
\mathrm{P}(p \text {-anisyl })_{3} \\
\mathrm{PBu}_{3}^{n}\end{array}$ & $\begin{array}{l}2,052 \\
2,045 \\
2,042 \\
2,039\end{array}$ & $\begin{array}{l}\text { " } \\
\text { " } \\
\text { " }\end{array}$ & $\begin{array}{l}0 \\
0 \\
0 \\
0\end{array}$ & $\begin{array}{l}\text { " } \\
\text { "1 } \\
\text { " }\end{array}$ & $\begin{array}{l}0 \\
0 \\
0 \\
0\end{array}$ & $\begin{array}{c}62.8 \\
11.0 \\
6.13 \\
0.46\end{array}$ \\
\hline
\end{tabular}

* S: Ethyl vinyl ether.

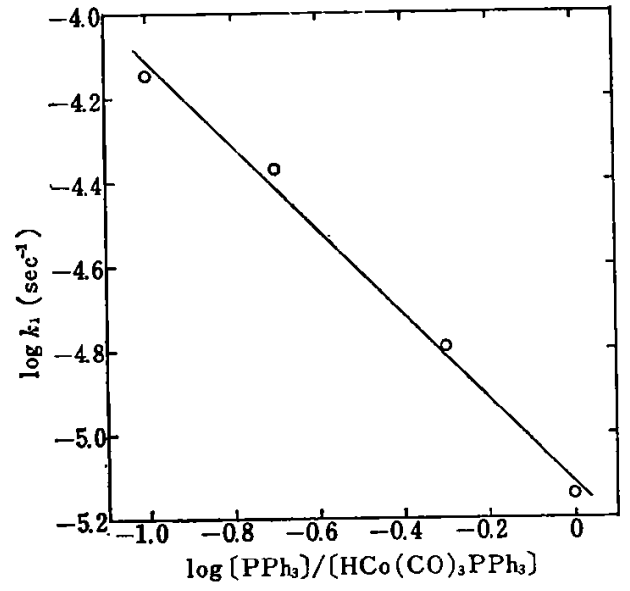

Fig. 2 The Effect of an Excess of Triphenylphosphine on the Rate Constant $\left(0^{\circ} \mathrm{C}\right.$, [HCo$\left.(\mathrm{CO})_{3} \mathrm{PPh}_{3}\right]=0.162 \mathrm{M}$ )

ducts (the straight/branched ratio) and the rate of catalytic hydroformylation depend on the ratio of phosphine to cobalt ${ }^{1}$. And so the influence of excess of triphenylphosphine on the stoichiometric reaction of $\mathrm{HCo}(\mathrm{CO})_{3} \mathrm{PPh}_{3}$ has been examined. The effect of excess of triphenylphosphine is drastic, and equivalent excess was shown to decrease the reaction rate by a factor of about 24. In Fig. 2, the rate constants are plotted against the concentrations of added triphenylphosphine. It shows a clear-cut interdependence between them, and the slope of the plots in Fig. 2 is about -1 , while the addition of an excess of triphenylphosphine has no effect on the distribution of the product, for the iodine-ethanol treatment of the reaction mixture gave only the branched chain ester.

The hydroformylation reaction catalyzed by
$\mathrm{Co}_{2}(\mathrm{CO})_{8}$ is retarded by high partial pressure of carbon monoxide, and cobalt hydrotricarbonyl is postulated to be the real active species ${ }^{7}$, which is formed by the dissociation of a carbon monoxide from cobalt hydrotetracarbonyl. The dissociation

$$
\begin{aligned}
& \mathrm{HCo}(\mathrm{CO})_{4} \longrightarrow \mathrm{HCo}(\mathrm{CO})_{3}+\mathrm{CO} \\
& \mathrm{HRh}(\mathrm{CO})\left(\mathrm{PPh}_{3}\right)_{3} \longrightarrow \mathrm{HRh}(\mathrm{CO})\left(\mathrm{PPh}_{3}\right)_{2}+\mathrm{PPh}_{3}
\end{aligned}
$$

of triphenylphosphine is also noted in the HRh(CO) $\left(\mathrm{PPh}_{3}\right)_{3}$ catalyst ${ }^{8}$. In the consideration of the effects of the phosphines in the reaction of $\mathrm{HCo}(\mathrm{CO})_{3} \mathrm{PR}_{3}$, the following three factors may mainly be taken into account; i) the dissociation of carbon monoxide from $\mathrm{HCo}(\mathrm{CO})_{3} \mathrm{PR}_{3}$, ii) the alkyl migration from cobalt to carbon monoxide (insertion), and iii) the dissociation of the phosphine from $\mathrm{HCo}(\mathrm{CO})_{3} \mathrm{PR}_{3}$.

$$
\begin{aligned}
& \mathrm{HCo}(\mathrm{CO})_{3} \mathrm{PR}_{3}+\mathrm{CO} \rightleftharpoons \mathrm{HCo}(\mathrm{CO})_{4}+\mathrm{PR}_{3} \\
& \mathrm{HCo}(\mathrm{CO})_{4} \rightleftharpoons \mathrm{HCo}(\mathrm{Co})_{3}+\mathrm{CO}
\end{aligned}
$$

Among these, however, the last seems to be most reasonable, judging from the result shown in Fig. 2. In the tungsten-tertiary phosphine system, Angelici and Ingemanson ${ }^{9)}$ have reported that the greater the $\sigma$-donating ability of a phosphine is, the more strongly the phosphine coordinates with the metal. If a similar conclusion is applicable to the present system, the dissociation of the phosphine is also consistent with the parallelism between the rate constants and the wave numbers of $\mathrm{CO}$ stretching.

The reaction of $\mathrm{HCo}(\mathrm{CO})_{4}$ with ethyl vinyl ether was too fast for kinetic studies.

The reaction rate of $\mathrm{HCo}(\mathrm{CO})_{3} \mathrm{P}(\mathrm{OR})_{3}$ did not obey the first order rate equation, and was too 


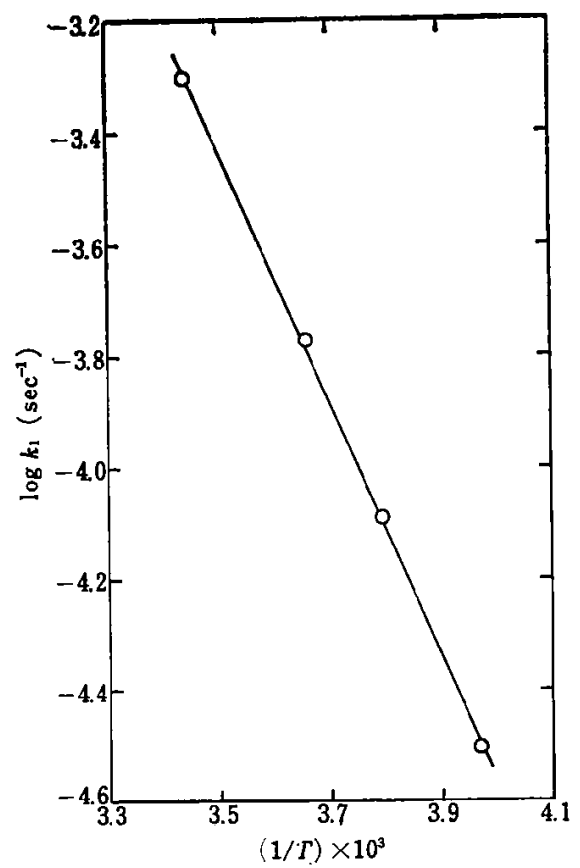

Fig. 3 Arrhenius Plots

complicated to be analyzed satisfactorily. Probably, this is partly attributed to the formation of $\mathrm{HCo}(\mathrm{CO})_{2}\left[\mathrm{P}(\mathrm{OR})_{3}\right]_{2}$ by addition of a phosphite to $\mathrm{HCo}(\mathrm{CO})_{4}$. Judging from the initial rate of absorption of carbon monoxide, $\mathrm{HCo}(\mathrm{CO})_{3}$ $\mathrm{P}(\mathrm{OPh})_{3}(\sim 5 \mathrm{~m} / / \mathrm{min})$ has reacted more readily with ethyl vinyl ether than $\mathrm{HCo}(\mathrm{CO})_{3} \mathrm{P}(\mathrm{OEt})_{3}$ $(\sim 3 \mathrm{~m} / / \mathrm{min})$ at $0^{\circ} \mathrm{C}$.

\subsubsection{Activation Parameters}

The temperature of the reaction of $\mathrm{HCo}(\mathrm{CO})_{3}$ $\mathrm{PPh}_{3}$ was varied in the range $-21.0 \sim+17.5^{\circ} \mathrm{C}$. Figure 3 shows the Arrhenius plots. The activation parameters were evaluated from the slope and the intercept as follows;

$$
\Delta \mathrm{H}^{+}=9.88 \mathrm{kcal} / \mathrm{mol}, \Delta \mathrm{S}^{\mp}=-41.0 \text { e.u. }
$$

There are no examples to be compared with the activation parameters obtained here, but close values are estimated in the $\mathrm{CO}$ exchange with $\mathrm{Ni}(\mathrm{CO})_{4}{ }^{10)}$. Further investigations are necessary in order to clucidate the meaning of the enthalpy and the negative entropy of activation.

\section{References}

1) For a relevant review; Paulik, F. E., Catal. Rev., 6, 49 (1972).

2) Hieber, W., Duchatsch, H., Chem. Ber., 98, 2933 (1965), and references cited therein.

3) Takegami, Y., Yokokawa, C., Watanabe, Y., Okuda, Y., Bull. Chem. Soc. Japan, 37, 181 (1964).

4) Mann, F. F., Chaplin, E. J., J. Chem. Soc., 516 (1937)

5) 1,1,2-Triethoxypropane was also formed, which was believed to be derived from $\alpha$-ethoxypropionaldehyde given by the further attack of $\mathrm{HCo}(\mathrm{CO})$, to $\alpha$-ethoxypropionylcobalt complex formed in the reaction of $\mathrm{HCo}(\mathrm{CO})_{4}$ with ethyl vinyl ether under carbon monoxide.

6) Tucci, E. R., Ind. Eng. Chem. Prod. Res. Develop., 9, $516(1970)$.

7) Orchin, M., Rupilius, W., Catal. Rev., 6, 85 (1972).

8) Montelatici, S., Ent, A. v. d., Osborn, J. A., Wilkinson, G., J. Chem. Soc. (A), 1054 (1968).

9) Angelici, R. J., Ingemanson, C. M., Inorg. Chem., 8, 83 (1969).

10) Kangas, L. R., Heck, H. F., Henry, P. M., Breitschaft, S., Thorsteinson, E. M., Basolo, F., J. Am. Chem. Soc., 88, 2334 (1966). 